\title{
Desain Konsep Self-Propelled Backhoe Dredger untuk Operasi Wilayah Sungai Kalimas Surabaya
}

\author{
Fajar Andinuari dan Hesty Anita Kurniawati \\ Departemen Teknik Perkapalan, Fakultas Teknologi Kelautan, Institut Teknologi Sepuluh Nopember (ITS) \\ e-mail: tita@na.its.ac.id
}

\begin{abstract}
Abstrak-Sungai Kalimas merupakan sungai utama di wilayah Surabaya, Jawa Timur. Selain itu, Sungai Kalimas juga berfungsi sebagai penunjang kehidupan sehari-hari warga Kota Surabaya. Fungsi kalimas sebagai sungai pelayaran kapal-kapal kecil telah lama hilang. Namun sejak Walikota Surabaya Tri Rismaharini memimpin, telah banyak perubahan pada wajah kota Surabaya, khususnya Sungai Kalimas. Bahkan, Walikota tak segan untuk menjadikan Sungai Kalimas sebagai daya tarik wisata Kota Surabaya. Namun di balik itu, karakteristik Sungai Kalimas yang mudah terendap oleh sedimentasi bisa menjadi masalah. Dalam waktu yang berkala, pemerintah melakukan pengerukan jika sungai mulai dangkal. Tetapi, proses pengerukan tersebut kurang begitu efektif karena pada akhirnya hasil keruk diletakkan di bibir sungai sebelum akhirnya dibawa oleh truk menuju tempat pembuangan. Oleh karena itu, dibutuhkan kapal keruk yang benar-benar sesuai dengan karakteristik dan struktur geometris Sungai Kalimas. Kapal keruk yang digunakan adalah jenis SelfPropelled Backhoe Dredger karena sangat cocok dengan struktur geometris sungai. Untuk mendapatkan ukuran utama kapal, maka dilakukan perhitungan analisis teknis dan estimasi biaya pembangunan dengan batasan-batasan yang telah ditentukan. Dari hasil analisis teknis, didapatkan ukuran utama kapal antara lain $\mathrm{L}_{\mathrm{wl}}=16,62 \mathrm{~m}, \mathrm{~L}_{\mathrm{pp}}=16,25 \mathrm{~m}, \mathrm{~B}=\mathbf{9 , 0 0} \mathrm{m}, \mathrm{H}=\mathbf{2 , 8 0} \mathrm{m}$, dan $\mathrm{T}=$ $1,78 \mathrm{~m}$ dengan estimasi biaya pembangunan sebesar Rp2.800.724.568.
\end{abstract}

Kata kunci-Pengerukan, Self-Propelled Backhoe Dredger, Sungai Kalimas Surabaya.

\section{PENDAHULUAN}

$\mathrm{S}$ UNGAI Kalimas adalah sungai yang terletak di wilayah kota Surabaya. Sungai Kalimas juga merupakan komponen penting dalam pertumbuhan dan perkembangan masyarakat kota Surabaya. Sungai Kalimas pernah memiliki pelabuhan besar sejak zaman Majapahit pada abad 14 hingga masa kependudukan Belanda tahun 1746. Namun, pada tahun 1910 pemindahan pelabuhan ke Tanjung Perak dilakukan karena kendala bongkar muat. Pasca penurunan aktivitas yang terjadi seiring dengan mode transportasi yang lebih baik, Pelabuhan Kalimas berganti nama menjadi Pelabuhan Pelayaran Rakyat (PELRA) [1].

Sayangnya, saat ini aktivitas Pelayaran Rakyat sangat susut baik karena faktor kemajuan teknologi maupun lingkungan pendukung. Seiring berjalannya waktu, Kalimas lebih sering dianggap simbol sampah karena memang masyarakat Surabaya sendiri masih banyak yang menjadikan sungai Kalimas sebagai tempat sampah. Hanya saja saat Ibu Walikota Tri Rismaharini menjabat, setidaknya sungai Kalimas dapat kembali bersih namun masih relatif. Selain sampah, masalah lainnya adalah karakteristik struktur tanah sungai kalimas yang mudah tersedimentasi juga dapat menyebabkan volume tampung air jadi turun. Dari kedua masalah tersebut, lingkungan pendukung yang salah akan menyulitkan penghidupan kembali Pelayaran Rakyat di Sungai Kalimas tanpa adanya solusi yang tepat. Proses pengerukan sungai Kalimas merupakan salah satu upaya pemerintah Surabaya untuk memperbaiki kondisi sungai. Fungsi dari pengerukan tersebut adalah bermacam-macam, antara lain untuk membersihkan sampah, memperbaiki sistem drainase kawasan Surabaya, mereklamasi kedalaman air sungai, dll. Namun masih ada fungsi lain yang dapat menghidupkan Pelayaran Rakyat sebagai daya wisata di Kalimas, yaitu perbaikan jalur sungai untuk kapal-kapal kecil yang melintas. Karena dengan kondisi Kalimas kini yang penuh dengan sampah dan dangkal, akan sangat merugikan performa kapal-kapal kecil yang melintas.

\section{TINJAUAN PUSTAKA}

\section{A. Pekerjaan Pengerukan}

Pengerukan adalah suatu pekerjaan mengubah bentuk dasar perairan untuk mencapai kedalaman dan lebar yang dikehendaki atau untuk mengambil material dasar laut perairan yang dipergunakan untuk keperluan tertentu [2]. Pengerukan adalah bagian dari Ilmu Sipil yang berarti pemindahan material dari dasar bawah air, atau setiap kegiatan yang merubah konfigurasi dasar atau kedalaman perairan seperti laut, pantai, sungai, danau, ataupun daratan untuk mencapai suatu elevasi tertentu dengan menggunakan peralatan keruk [3].

\section{B. Klasifikasi Pengerukan}

Berdasarkan pemanfaatan material keruknya, pekerjaan pengerukan dibagi atas:

a. Pekerjaan pengerukan yang hasil material keruknya dapat dimanfaatkan, dimana hasil pemanfaatannya harus mendapatkan persetujuan dari instansi yang berwenang.

b. Pekerjaan pengerukan yang hasil material keruknya dibuang atau tidak dimanfaatkan, sesuai rekomendasi dari syahbandar dan penyelenggara pelabuhan terdekat.

Sedangkan berdasarkan jenis kegiatannnya, dibagi atas:

a. Kegiatan pembangunan atau pengerukan awal (Capital Dredging)

Capital Dredging adalah kegiatan pengerukan untuk membuat suatu konfigurasi dasar laut, sungai, atau danau yang baru. 
b. Kegiatan pengerukan pemeliharaan (Maintenance Dredging)

Maintenance Dredging adalah kegiatan pengerukan untuk mempertahankan konfigurasi dasar laut, sungai, atau danau tersebut [4].

\section{Tujuan Pengerukan}

Adapun berikut beberapa tujuan pengerukan dilakukan:

1. Konstruksi dan reklamasi

Untuk memperoleh material bangunan seperti kerikil, pasir, dan tanah liat atau untuk menimbun lahan dengan material kerukan sebagai tempat membangun daerah industri, permukiman, jalan, dsb.

2. Pertambangan

Untuk mendapatkan mineral, permata, logam mulia, dan pupuk.

3. Pelayaran (Navigasi)

Untuk perluasan, pemeliharaan, dan perbaikan sarana lalu lintas air dan pelabuhan. Untuk membuat pelabuhan, memperdalam kolam pelabuhan (turning basin), dan fasilitas lainnya.

4. Pengendalian banjir

Untuk memperbaiki dan melancarkan aliran sungai dengan memperdalam dasar sungai atau fasilitas pengendali banjir lainnya seperti tanggul atau bendungan.

5. Tujuan lainnya

Untuk penggalian pondasi bawah air dan penanaman pipa saluran air atau pembuatan terowongan. Untuk membuang polutan dan mendapatkan air yang berkualitas [5].

\section{Siklus Waktu Pengerukan}

Proses pengerjaan pengerukan akan melalui 4 tahap, yaitu:

1. Tahapan memotong/excavating

2. Tahapan menaikkan/lifting

3. Tahapan mengangkut/transportation

4. Tahapan membuang/dumping

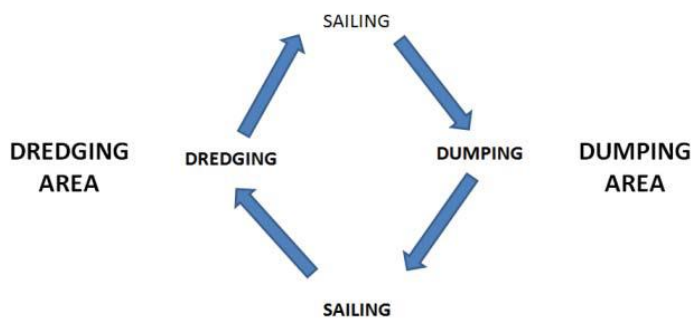

Gambar 1. Siklus Pengerukan

Gambar 1 adalah siklus pengerukan dan tahapan yang dilakukan pada dasarnya hanya dengan tiga mekanisme, yakni:

1. Pengerukan Hidrolik

Pengerukan untuk material yang lepas/loose/tidak padat, biasanya untuk Maintenance Dredging.

2. Pengerukan Mekanik

Pengerukan untuk material yang padat/solid, biasanya untuk Maintenance Dredging dan Capital Dredging.

3. Pengerukan Hidrolik dan Mekanik

Kombinasi dari kedua metode sebelumnya, biasanya untuk material keras dan perlu dipotong sebelum material dihisap.
Ketiga cara pengerukan di atas juga menggunakan alat bantu untuk transportasi dan pembuangan material hasil pengerukan [3].

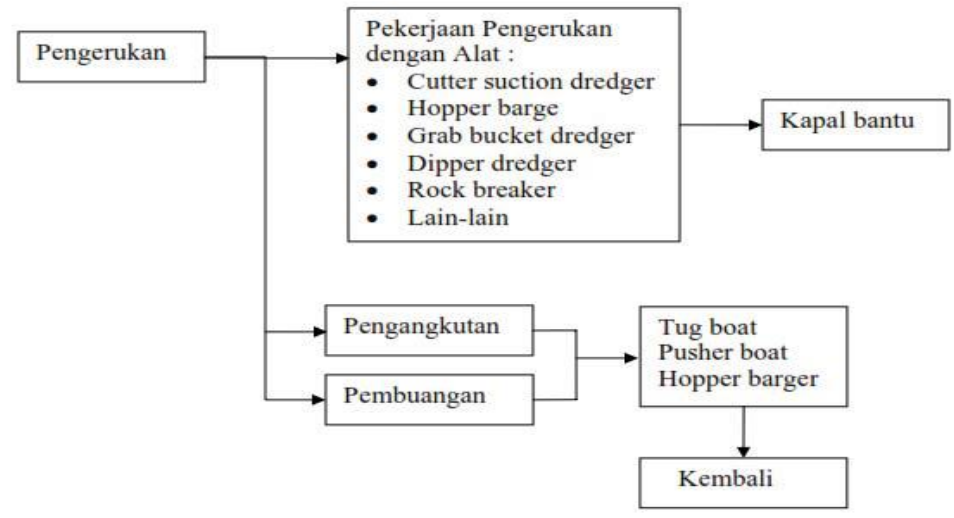

Gambar 2. Aktivitas Pengerukan

\section{E. Pemilihan Jenis Alat Keruk}

1. Jenis alat keruk berdasar penggeraknya dibedakan berdasarkan yang memiliki alat penggerak sendiri dan tanpa alat penggerak sendiri, dimana masing-masing jenis alat keruk memiliki kinerja berbeda untuk berbagai keadaan cuaca dan material tanah dasarnya.

2. Pemilihan jenis kapal keruk sangat penting dikarenakan dapat meningkatkan hasil yang lebih efisien dan lebih ekonomis, optimalisasi pengerukan, dan untuk mengurangi dampak dari sedimentasi.

3. Pemilihan jenis dan kapasitas kapal keruk ditentukan oleh:

a. Maksud dan tujuan dilakukan pengerukan (pemeliharaan kedalaman alur/kolam pelabuhan dan pembuatan alur/kolam pelabuhan).

b. Kedalaman awal alur atau kolam.

c. Jenis material keruk (pasir, lumpur, tanah liat/clay dan karang)

d. Lokasi pekerjaan

e. Volume keruk

f. Jarak ke area pembuangan (dumping area)

\section{F. Backhoe Dredger}

Backhoe merupakan salah satu alat dredging berbentuk timba dengan penggali hidrolis tunggal yang terletak di ujung lengan yang berbeda (depan atau belakang). Backhoe Dredger dipakai untuk penggalian di wilayah air yang merupakan pengembangan dari backhoe excavator yang ada di darat. Istilah backhoe bukanlah menunjukkan bahwa lokasinya terletak di belakang, akan tetapi ditinjau dari cara pengerukan yang dilakukan membelakangi material keruk.

Kapal keruk jenis ini mulai dikenal sejak tahun 1980-an. Saat itu, pembangunan Backhoe Dredger masih sangat jarang. Backhoe Dredger sangat cocok digunakan untuk wilayah perairan yang dangkal. Selain itu, kapal keruk jenis ini cocok jika dioperasikan untuk wilayah yang memiliki karakteristik material keruk yang berpasir, berbatu, atau campuran antara keduanya. Cara kerja Backhoe Dredger adalah sama seperti fungsi excavator pada umumnya. Dalam pembangunannya, halhal yang perlu diperhatikan yaitu batasan-batasan pada wilayah operasi, seperti sarat minimum, lebar minimum, dll. 


\section{G. Metode Desain Kapal}

Set Based Design adalah salah satu jenis metode desain kompleks yang juga digunakan dalam dunia perkapalan. Metode ini menggunakan sistem alternatif secara paralel, dimana melihat sesuatu yang jelas bernilai dan mengeliminasi yang dianggap tidak menguntungkan. Maksud dari sistem paralel adalah dilakukannya optimisasi terhadap suatu hal yang ditinjau. Kemudian dari banyak nilai optimisasi tersebut, akan diambil nilai yang benar-benar efisien. Dalam dunia perkapalan salah satu metode Set Based Design yang sering dipakai adalah metode 256 untuk mendapatkan hasil teroptimal yang mempengaruhi performa kapal dan cost pada pembangunan kapal.

\section{METODOLOGI}

\section{A. Bagan Alir}

Pada Gambar 3 berikut merupakan Bagan alir dari metodologi pengerjaan Studi ini:

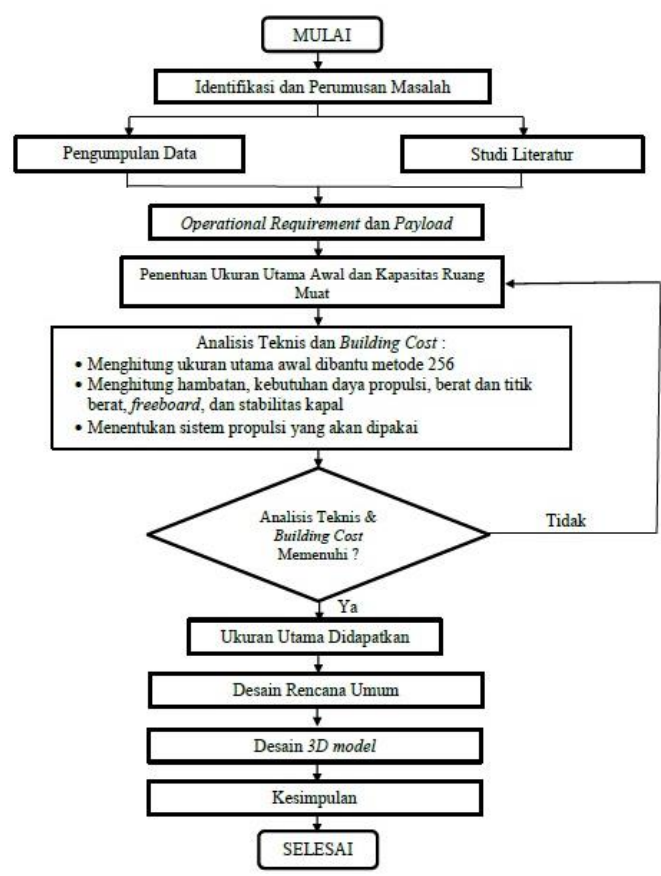

Gambar 3. Bagan Alir Metodologi

\section{B. Identifikasi dan Perumusan Masalah}

Identifikasi dilakukan guna mengetahui masalah apa saja yang dapat timbul dari obyek yang dituju antara lain tentang Sungai Kalimas, kapal keruk jenis backhoe dredger, dsb. Selanjutnya adalah merumuskan masalah dari masalah yang telah didapatkan. Fungsi dari perumusan masalah tidak lain agar penyelesaian dari masalah yang dibahas jelas.

\section{Pengumpulan Data dan Studi Literatur}

Pengumpulan data sangatlah diperlukan untuk mengetahui segala hal tentang obyek yang akan ditinjau. Pengumpulan data dapat dilakukan dengan berbagai cara antara lain, pengumpulan data primer dan sekunder. Selain mengumpulkan data, pengumpulan studi literatur juga harus dilakukan guna memperkuat teori yang dipakai.

\section{Perhitungan Teknis}

Perhitungan teknis meliputi perhitungan ukuran utama, hambatan kapal, berat dan titik berat kapal, lambung timbul (freeboard), trim, stabilitas dan estimasi biaya pembangunan (building cost).

\section{E. Desain Lines Plan, Rencana Umum, dan 3D Model}

Pada tahap ini, proses perencanaan model 3D, gambar Rencana Garis, dan gambar Rencana Umum didasarkan pada karakteristik Sungai Kalimas Surabaya.

\section{F. Kesimpulan}

Tahapan terakhir dalam penelitian ini adalah penarikan kesimpulan.

\section{G. Lokasi Pengerjaan}

Lokasi pengerjaan yang ditinjau pada Studi ini di Sungai Kalimas, berawal dari muara sungai sampai ke Jembatan Petekan Surabaya. Berikut penjabaran informasi peta lokasinya sesuai dengan Gambar 4.

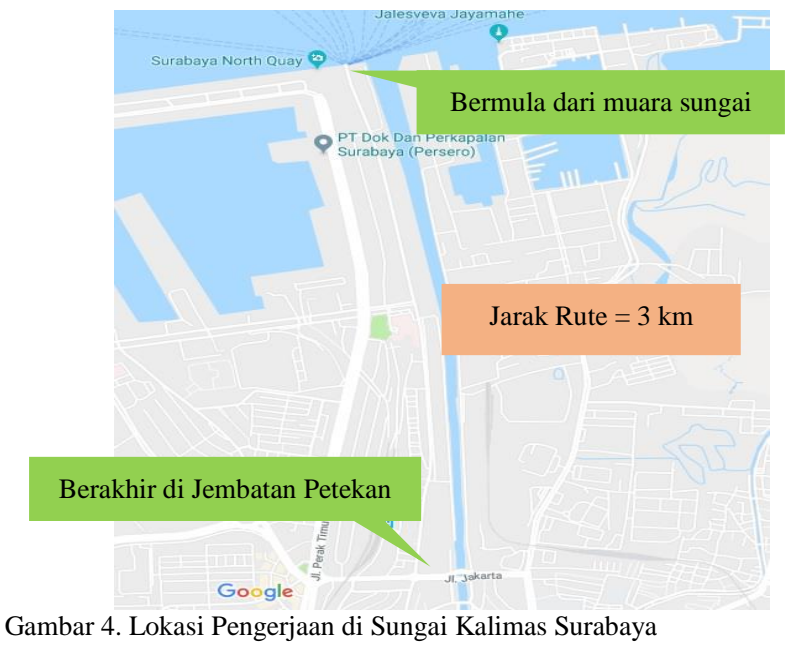

\section{ANALISIS TEKNIS DAN ESTIMASI BIAYA}

\section{A. Analisis Perhitungan Ruang Muat dan Ukuran Utama Awal}

Perhitungan ruang muat pada dredger vessel didasarkan pada struktur geometris Sungai Kalimas Surabaya yang meliputi kedalaman sungai, lebar minimum sungai, jenis sedimentasi dan volume sedimentasi. Data-data tersebut juga digunakan untuk menentukan Operational Requirements kapal.

Dari hasil perhitungan, maka didapatkan Payload kapal sebesar 94 ton. Dengan diperolehnya nilai Payload kapal akan didapatkan juga volume akibat muatan sebesar $126,0054 \mathrm{~m}^{3}$. Dari hasil volume tersebut, maka ukuran untuk ruang muat dapat diperkirakan sebagai dasar penentuan ukuran utama awal kapal. Hasil ukuran ruang muat kapal L (panjang), B (lebar), dan $\mathrm{H}$ (tinggi) masing-masing adalah $\mathrm{L}=8,6$ meter, $\mathrm{B}=6,8$ meter, dan $\mathrm{H}=2,2$ meter. Kemudian ukuran side tank dan tinggi double bottom masing-masing 0,6 meter. Perencanaan ruang muat dapat dilihat pada Gambar 5 berikut. 


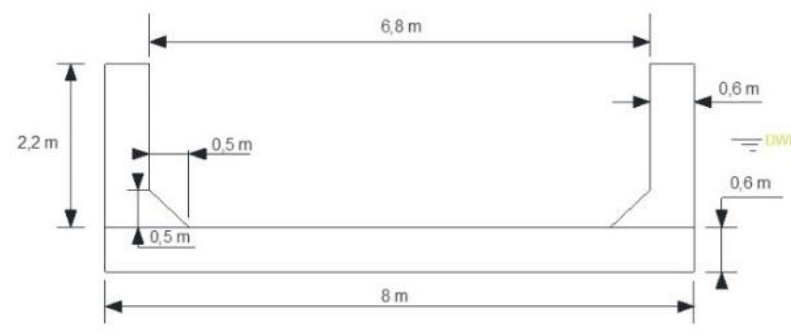

Gambar 5. Ukuran Ruang Muat Kapal

Setelah didapatkan ukuran ruang muat, proses selanjutnya adalah menentukan ukuran utama awal kapal. Rekapitulasi hasil perhitungan ukuran utama awal kapal dapat dilihat pada Tabel 1 berikut:

Tabel 1.

Rekapitulasi Ukuran Utama Awal Kapal

\begin{tabular}{cc}
\hline \multicolumn{2}{c}{ Rekapitulasi Ukuran Utama Awal Kapal } \\
\hline Ukuran Utama Awal Kapal & Nilai \\
\hline Panjang $\left(\mathrm{L}_{0}\right)$ & 15 meter \\
Lebar $\left(\mathrm{B}_{0}\right)$ & 8 meter \\
Tinggi $\left(\mathrm{H}_{0}\right)$ & 2,8 meter \\
Sarat $\left(\mathrm{T}_{0}\right)$ & 1,5 meter \\
\hline \hline
\end{tabular}

Ukuran utama awal di atas bersifat sementara karena pada proses-proses selanjutnya akan dioptimisasi berdasarkan aspekaspek teknis yang ditinjau.

\section{B. Metode Optimisasi 256 dan Perhitungan Main Coefficient}

Tahap setelah mendapatkan ukuran utama awal kapal adalah mengoptimisasi ukuran utama menggunakan metode 256. Dalam menggunakan metode 256 ini dibutuhkan beberapa variabel pendukung untuk mengoperasikannya. Variabel pendukung tersebut meliputi nilai Froude Number, L/B, B/T, dan $\mathrm{T} / \mathrm{H}$. Dengan adanya variabel pendukung tersebut, maka metode optimisasi 256 dapat dilakukan.

Tujuan metode 256 dilakukan adalah untuk mendapatkan ukuran utama kapal yang optimal berdasarkan aspek-aspek teknis yang ditinjau. Dalam operasinya, metode 256 dapat menghasilkan 256 ukuran utama kapal yang dipersentasekan pada batas atas dan batas bawah dari ukuran utama awal kapal yang telah diperoleh (variasi penambahan sebesar $\mathrm{x} \%$ ). Persentase batas atas metode 256 yang dipakai bernilai $-1,667$ $\%$ dan $-5 \%$. Begitu juga pada persentase batas bawah metode 256 bernilai $1,667 \%$ dan $5 \%$. Kemudian dari variasi penambahan tersebut, diperoleh nilai $\mathrm{Fn}_{0}, \mathrm{~L}_{0} / \mathrm{B}_{0}, \mathrm{~B}_{0} / \mathrm{T}_{0}, \mathrm{~T}_{0} / \mathrm{H}_{0}$ masing-masing sebanyak 4 (empat) nilai. Dari nilai-nilai tersebut selanjutnya digunakan untuk mendapatkan ukuran utama kapal sebanyak 256 ukuran utama.

Setelah sebanyak 256 ukuran utama kapal didapatkan dengan menggunakan metode 256 , proses selanjutnya adalah menghitung nilai main coefficient dan LCB kapal yang rekapitulasinya dapat dilihat pada Tabel 2 berikut.

Tabel 2.

Main Coefficient

\begin{tabular}{cc}
\hline \hline Main Coefficient & Nilai \\
\hline Block Coefficient $\left(\mathrm{C}_{\mathrm{b}}\right)$ & 0,612 \\
Midship Coefficient $\left(\mathrm{C}_{\mathrm{m}}\right)$ & 1,000 \\
Waterplane Coefficient $\left(\mathrm{C}_{\mathrm{wp}}\right)$ & 0,547 \\
Prismatic Coefficient $\left(\mathrm{C}_{\mathrm{p}}\right)$ & 0,612 \\
LCB Length $($ from $A P)$ & $7,965 \mathrm{~m}$ \\
\hline \hline
\end{tabular}

Setelah itu, dilakukan analisis teknis seperti perhitungan hambatan kapal, daya yang dibutuhkan kapal, pengecekan freeboard, trim, dan stabilitas.

\section{Ukuran Utama Self-Propelled Backhoe Dredger}

Setelah analisis teknis dilakukan, tahap selanjutnya adalah memilih ukuran utama kapal dari semua ukuran utama yang ada. Pemilihan ukuran utama haruslah jelas dan harus memiliki dasar. Dari sekian banyak perhitungan analisis teknis yang telah dilakukan, terdapat beberapa ukuran utama yang tidak memenuhi ketentuan. Pada Tabel 3 berikut merupakan ukuran utama kapal yang dipilih:

Tabel 3 .

Ukuran Utama Kapal

\begin{tabular}{cc}
\hline \hline Ukuran Utama & Nilai \\
\hline Panjang Garis Air $\left(\mathrm{L}_{\mathrm{wl}}\right)$ & $16,62 \mathrm{~m}$ \\
Panjang antara Dua Garis Tegak $\left(\mathrm{L}_{\mathrm{pp}}\right)$ & $16,25 \mathrm{~m}$ \\
Lebar $(B)$ & $9,00 \mathrm{~m}$ \\
Tinggi (H) & $2,80 \mathrm{~m}$ \\
Sarat $(\mathrm{T})$ & $1,78 \mathrm{~m}$ \\
\hline \hline
\end{tabular}

Dari hasil optimisasi menggunakan metode 256, ukuran utama kapal yang memiliki Displacement dan dapat menampung berat kapal keseluruhan adalah ukuran utama yang diberikan pada Tabel 3 di atas. Sedangkan untuk Length between Perpendicular $\left(\mathrm{L}_{\mathrm{pp}}\right)$ diperoleh dari $\pm \mathrm{Lwl}-0,37 \mathrm{~m}$, karena terdapat perencanaan letak kemudi (rudder) kapal.

\section{Estimasi Biaya Pembangunan Kapal}

Proses menghitung biaya pembangunan kapal ini berdasarkan komponen-komponen apa saja yang direncanakan terdapat di kapal. Kemudian mulai mencari harga pasaran dari komponen-komponen tersebut. Komponen-komponen yang dihitung antara lain harga pelat kapal, square piles, Backhoe Komatsu PC 200-7, main engine, generator set, dan elektroda las. Dari komponen-komponen tersebut, total biaya pembangunan kapal (buliding cost) yang diperoleh sebesar Rp2.800.724.568.

\section{E. Desain Rencana Garis (Lines Plan)}

Pembuatan Rencana Garis Kapal dilakukan menggunakan bantuan software. Gambar 6 berikut merupakan Rencana Garis Kapal.
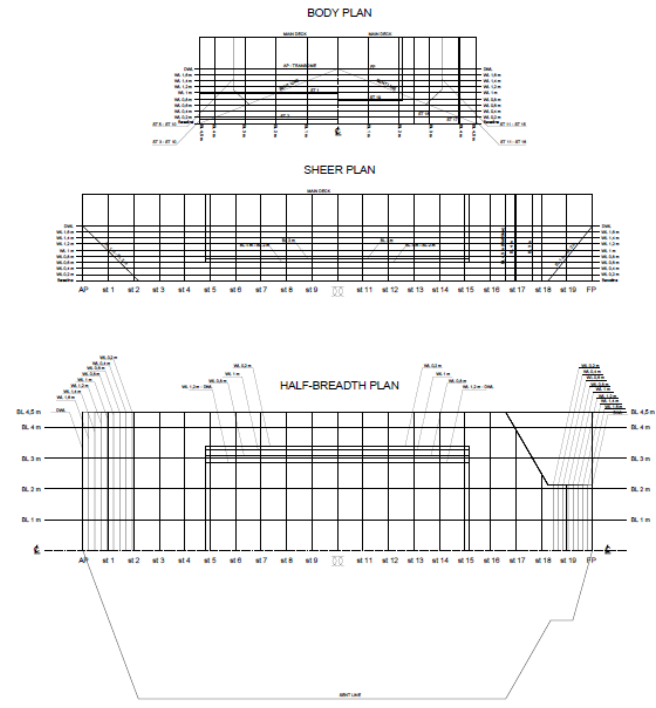

Gambar 6. Rencana Garis 


\section{F. Desain Rencana Umum}

Rencana umum dapat didefinisikan sebagai gambar perencanaan dan pembagian ruang untuk semua kebutuhan dan perlengkapan kapal sesuai lokasi dan akses yang dibutuhkan. Rencana umum dibuat berdasarkan rencana garis yang telah dibuat sebelumnya sehingga memudahkan dalam merencanakan serta menentukan pembagian ruangan sesuai dengan fungsinya masing-masing. Rencana Umum Kapal dapat dilihat pada Gambar 7.

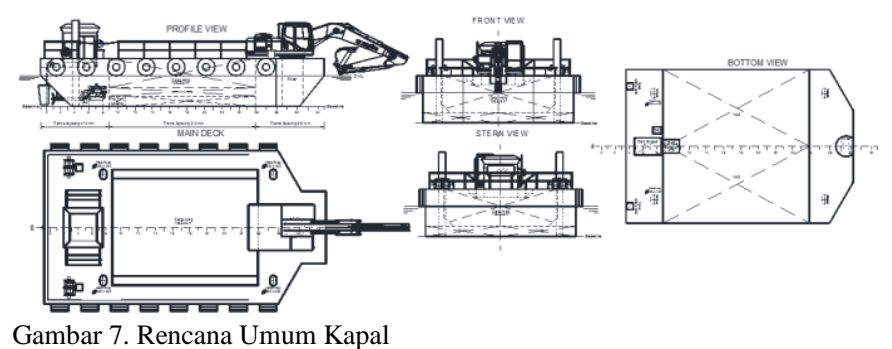

G. Desain Model 3D

Pembuatan model 3D menggunakan bantuan software. Hasil model 3D dapat dilihat Gambar 8.

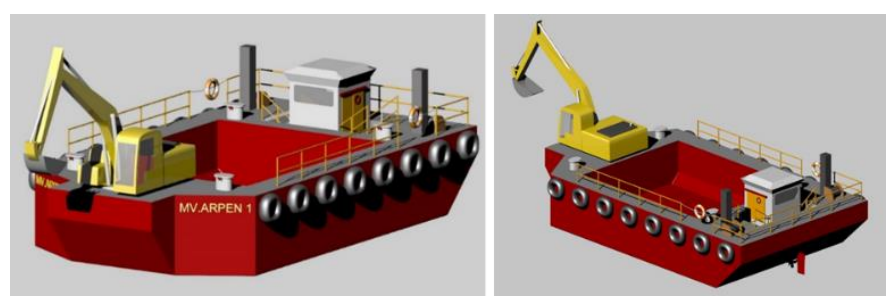

Gambar 8. Model 3D Self-Propelled Backhoe Dredger

\section{KESIMPULAN}

Setelah dilakukan penelitian, maka kesimpulan dari Studi ini adalah sebagai berikut:

1. Dari hasil analisis yang telah dilakukan, diperoleh ukuran utama Self-Propelled Backhoe Dredger sebagai berikut:

- Length of Waterline $\left(\mathrm{L}_{\mathrm{wl}}\right) \quad=16,62 \mathrm{~m}$

- Length Between Perpendicular $\left(\mathrm{L}_{\mathrm{pp}}\right)=16,25 \mathrm{~m}$

- Breadth (B) $\quad=9,00 \mathrm{~m}$

- Height $(\mathrm{H}) \quad=2,80 \mathrm{~m}$

- Draught $(\mathrm{T}) \quad=1,78 \mathrm{~m}$

2. Dari hasil analisis perhitungan kapasitas muatan keruk, diperoleh besar kapasitas muatan keruk yang dapat ditampung oleh kapal (Payload) sebesar 94 ton.

3. Dari hasil perhitungan Building Cost yang telah dilakukan, diperoleh harga biaya pembangunan kapal sebesar Rp2.800.724.568.

\section{DAFTAR PUSTAKA}

R. Hastijanti, "Permasalahan Dan Solusi Pelestarian Kawasan Kota Lama Kalimas," in Seminar Pelestarian Kawasan Kota Lama, 2010.

[2] D. P. dan Pengerukan, Pedoman Teknis Pengerukan Alur Pelayaran di Laut dan Kolam Pelabuhan. Jakarta: Kementerian Perhubungan, Direktorat Jenderal Perhubungan Laut, 2015.

[3] J. Mahendra, Dunia Dredging \& Reklamasi di Indonesia. Depok, 2014.

[4] D. P. dan Pengerukan, Pedoman Teknis Kegiatan Pengerukan dan Reklamasi. Jakarta: Kementerian Perhubungan, Direktorat Jenderal Perhubungan Laut, 2006.

[5] M. A. Rohim, "Penentuan Prototipe Kapal Keruk Yang Sesuai Untuk Dermaga Umum Pelabuhan Gresik," Institut Teknologi Sepuluh Nopember, 2003. 